\title{
Mortality study of workers employed at a plant manufacturing chemicals for the rubber industry: 1955-86
}

\author{
Tom Sorahan, Debbie Pope
}

A chronic gavage study on rats and mice carried out by the US National Toxicology Program found that 2-mercaptobenzothiazole (MBT) produced some evidence of carcinogenic activity in male and female rats. ${ }^{1}$ A chronic feeding study with mice provided no evidence for involvement of MBT in the neoplastic process. ${ }^{2}$ The relevance of these findings to workers exposed at work to MBT (or its derivatives) is uncertain, and information on the safety (or otherwise) of MBT has been sought by means of an epidemiological investigation.

MBT is manufactured and used at a chemicals production plant in north Wales, along with vulcanisation inhibitors and accelerators, antioxidants, and many other proprietary products for the rubber industry. It was first manufactured on the site in 1932. Operations also involved sodium MBT and zinc MBT. Production of MBT derivatives such as dibenzothiazyl disulphide (MBTS), n-oxydiethylene-2-benzothiazolesulphenamide (MBS), and n-cyclohexyl-2-benzothiazolesulphenamide (CBS) began in 1939. After discussions with company medical advisers and occupational hygienists, the occupational exposures to the following compounds were also selected for investigation: (1) polymerised 2,2,4-trimethyl-1,2-dihydroquinoline (TMQ), (2) n-cyclohexylthiophthalimide (CTP), (3) phenyl- $\beta$-napthylamine (PBN), and (4) aniline and orthotoluidine. The results of an analysis of cancer mortality experienced by production workers employed at this plant are reported here.

A mortality study of chemical production workers exposed to MBT is also being carried out at a United States plant that has processes in common with the United Kingdom plant.

Cancer Epidemiology Research Unit, Department of Public Health and Epidemiology, University of Birmingham, Edgbaston, Birmingham B15 2TT Tom Sorahan, Debbie Pope

\section{Materials}

The company supplied a computer tape comprising identifying particulars for all employees known to have worked at the plant in the period 1955-84 and detailed coded job histories (for hourly paid personnel only). Two subcohorts were identified; a survivor population in employment on 1 January 1955 and an entry cohort of employees who commenced work in the period 1955-84. Employees working for less than six months were excluded. The classification of salaried and hourly staff referred to the most recent job carried out at the plant and it was necessary to categorise personne on the basis of first job. Job histories for all salarie personnel were sought, therefore, both from paper and microfilmed records stored in the company's personnel department. A number of such employees were found to have commenced employment at $\mathrm{a}$ the plant as hourly paid staff, and the final data file contained information on 2410 hourly paid personnel and 312 salaried personnel (based on first job). The analysis proceeded on the basis of the hourly paid staff only (men: survivor population ( $n=1549)$, entry cohort $(n=611)$; women: survivor population $(n=86)$, entry cohort $(n=164)$.

A comparison of some 200 computerised job 3 history records with source data indicated that data 8 abstraction had been thorough, but a review of all $₹$ original records was necessary to obtain further identifying particulars for tracing the study population (full names rather than initials, and addresses that were not available in the computerised data). Several sources were used for tracing and vital sta- $\sigma$ tus for some $98 \%$ of the cohort was determined $N$ (see table 1). Cause of death was ascertained for $N$ some $98 \%$ of the identified deaths.

Job histories were available in terms of some 300 job and department titles. A former occupational hygienist from the plant provided assessments of $\stackrel{\mathscr{Q}}{\rightarrow}$ eight hour time weighted average exposures to both 0 MBT and MBT derivatives for different years and 0 for each job and department title. Jobs attracted either zero exposure, very low $\left(0-1 \mathrm{mg} / \mathrm{m}^{3}\right)$, low 
Table 1 Vital status at closing date of study (31 December 1986)

\begin{tabular}{lrr}
\hline Vital status & No & $\%$ \\
\hline Traced alive, still employed & 300 & $12 \cdot 4$ \\
Traced alive, pensions department & 432 & $17 \cdot 9$ \\
Flagged alive at NHSCR & 638 & $26 \cdot 5$ \\
Traced alive by NI offices & 59 & $2 \cdot 4$ \\
Emigrated & 22 & $0 \cdot 9$ \\
Died, cause known & 894 & $37 \cdot 1$ \\
Died, cause not known & 14 & $0 \cdot 6$ \\
No trace & 51 & $2 \cdot 1$ \\
Total & 2410 & $100 \cdot 0$ \\
\hline
\end{tabular}

(1-2.5 $\left.\mathrm{mg} / \mathrm{m}^{3}\right)$, medium $\left(2 \cdot 5-6 \mathrm{mg} / \mathrm{m}^{3}\right)$, or high exposure $\left(6-20 \mathrm{mg} / \mathrm{m}^{3}\right)$. Estimates were made on the basis of monitoring data for the period 1977 onwards, a review of process manuals and other company records for earlier years, and discussions with long serving employees. Annual exposure estimates had been adjusted by a "year fraction" factor to take into account the fact that some jobs would not be associated with exposure to MBT throughout the whole of the working year. In this analysis, arithmetic means of the adjusted exposure ranges were used as point estimates of exposure concentration, and individual cumulative exposures (time dependent variable) were estimated by the sum of the products of duration of employment and relevant exposure concentration $\left(\mathrm{mg} \cdot \mathrm{m}^{-3}\right.$ years). MBT and derivatives of MBT have been considered as a single entity, and exposures to each have been combined. Separate assessments were provided of job and department titles involving appreciable exposures either to TMQ, $\mathrm{PBN}$, aniline or orthotoluidine, or CTP.

\section{Methods}

Expectations were calculated from serial mortalities for England and Wales applied to similarly defined arrays of person-years at risk (pyr) generated by the data. Workers enter the pyr at the end of the six months minimum period of employment, or 1 January 1955, whichever is the later date. They leave the pyr on the closing date of the study (31 December, 1986), the date of death, the date of emigration, or date last known alive, whichever is the earlier date. For the occupationally exposed subcohorts, subjects enter the pyr at the end of the six months minimum period of employment, on 1 January 1955, or the date first employed in an exposed job, whichever is the later date. For analyses by amount of cumulative exposure to MBT, workers may contribute pyr to more than one exposure level (cumulative exposure is treated as a timedependent variable).

Significance tests are two tailed and standardised mortality ratios (SMRs) and p values have been calculated from expectations calculated to three places of decimals, rather than from those shown in the tables. No contributions are made to observed or expected numbers past the age of 85 years.

\section{Results}

Mortality from all causes was analysed both by age at death and year of death to seek evidence of inadequate tracing of deaths. No such evidence was found. Table 2 shows observed and expected numbers of deaths for all causes and all neoplasms by years from first employment. Some $80 \%$ of the observed deaths occurred 20 or more years after first employment, and only 3\% occurred in the first 10 years. For both men and women, overall SMRs for mortality from cancer (98 and 71 respectively) were lower than those for all causes (100 and 95 respectively). For both causes, the trend of SMRs increasing with years from first employment was suggestive of a healthy worker effect. ${ }^{3}$ Similar findings were obtained for the male survivor population and entry cohort.

Table 2 Mortality from all causes and all neoplasms by years from first employment, 1955-86

\begin{tabular}{|c|c|c|c|c|c|c|}
\hline \multirow{2}{*}{$\begin{array}{l}\text { Years since } \\
\text { first } \\
\text { employment* }\end{array}$} & \multicolumn{3}{|c|}{$\operatorname{Men}(n=2160)$} & \multicolumn{3}{|c|}{ Women $(n=250)$} \\
\hline & $\operatorname{Exp}$ & Obs & $S M R$ & $\operatorname{Exp}$ & Obs & $S M R$ \\
\hline $\begin{array}{c}\text { All causes: } \\
0-9 \\
10-19 \\
20-29 \\
\geqslant 30\end{array}$ & $\begin{array}{r}38 \cdot 6 \\
154 \cdot 2 \\
277 \cdot 2 \\
374 \cdot 0\end{array}$ & $\begin{array}{r}27 \\
139 \\
282 \\
397\end{array}$ & $\begin{array}{r}70 \\
90 \\
102 \\
106\end{array}$ & $\begin{array}{r}5 \cdot 8 \\
13 \cdot 7 \\
15 \cdot 0 \\
10 \cdot 7\end{array}$ & $\begin{array}{r}2 \\
11 \\
15 \\
15\end{array}$ & $\begin{array}{r}35 \\
80 \\
100 \\
140\end{array}$ \\
\hline Total & $843 \cdot 9$ & 845 & 100 & $45 \cdot 1$ & 43 & 95 \\
\hline $\begin{array}{c}\text { All neoplasm } \\
0-9 \\
10-19 \\
20-29 \\
\geqslant 30\end{array}$ & $\begin{array}{r}9 \cdot 6 \\
40 \cdot 8 \\
73 \cdot 1 \\
95 \cdot 0\end{array}$ & $\begin{array}{l}7 \\
38 \\
75 \\
95\end{array}$ & $\begin{array}{r}73 \\
93 \\
103 \\
100\end{array}$ & $\begin{array}{l}2 \cdot 4 \\
5 \cdot 1 \\
4 \cdot 2 \\
2 \cdot 5\end{array}$ & $\begin{array}{l}1 \\
3 \\
3 \\
3\end{array}$ & $\begin{array}{c}42 \\
59 \\
72 \\
121\end{array}$ \\
\hline Total & 218.5 & 215 & 98 & $14 \cdot 1$ & 10 & 71 \\
\hline
\end{tabular}

*Irrespective of how long any worker remains in the industry. Exp = expected; Obs = observed. 
Table 3 shows observed and expected numbers of deaths by site of cancer and for broad noncancer groupings for men. None of the differences were statistically significant. Mortality from cancer of the stomach was above expectation (expected (exp) 23.9, Observed (obs) 29, SMR 121, 95\% confidence interval (95\% CI) 81-174), lung cancer was below expectation (exp $90 \cdot 5$, obs 78 , SMR 86 , 95\% CI 68-108), and bladder cancer was close to expectation (exp 8.6, obs 9, SMR 105, 95\% CI 48-199). There were only seven cancer deaths in the 10 year period after first employment (see table 2), and exclusion of this period of follow up from the analysis did not materially affect the results. (There were no deaths from bladder cancer among the entry cohort (exp 0.8).) The SMRs (1969-73) for the county in which the factory is situated are also shown (England and Wales = 100). Local rates tend to be higher than national rates for digestive cancers and lower for respiratory cancers. A similar pattern was shown for the study population. Similar analyses were carried out for women. Numbers of deaths for site specific cancers were small and none was significantly different from expectation.

Table 4 shows observed and expected numbers of deaths by site of cancer among workers exposed $\frac{3}{d}$ to MBT or its derivatives $(n=360 \mathrm{men})$. The $\stackrel{\circ}{?}$ SMR of 121 for all neoplasms was not significantly $\vec{\Rightarrow}$ different from 100 (95\% CI 84-168). None of the site specific SMRs was significantly different from 100 (oesophagus, 95\% CI 73-1040; large intestine, 95\% CI 94-674; rectum, 95\% CI 48-683; lung, 95\% CI 51-173; bladder, 95\% CI 56-792). Similar analyses for workers exposed to TMQ, workers of employed in the PBN plant, and workers exposed to aniline or orthotoluidine are also shown. In general, numbers of site specific cancer deaths available for analysis were small. None of the SMRs were statistically different from 100 . Similar analyses of workers exposed to CTP were based on even smaller numbers (all causes: exp 1.6, obs 0 ; all neoplasms: exp 0.5 , obs 0 ). For those employees exposed to MBT but not to aniline or orthotoluidine there was one observed death from bladder $₫$ cancer compared with an expectation of 0.66 .

Table 5 shows observed and expected numbers of deaths for all neoplasms and cancer of the blad- $Z$ der by amounts of cumulative exposure to MBT. Cut off values for amounts of exposure were chosen to represent exposures equivalent to five and 15 years employment in medium exposure jobs. For

Table 3 Mortality among men $(n=2160)$ †, $1955-86$

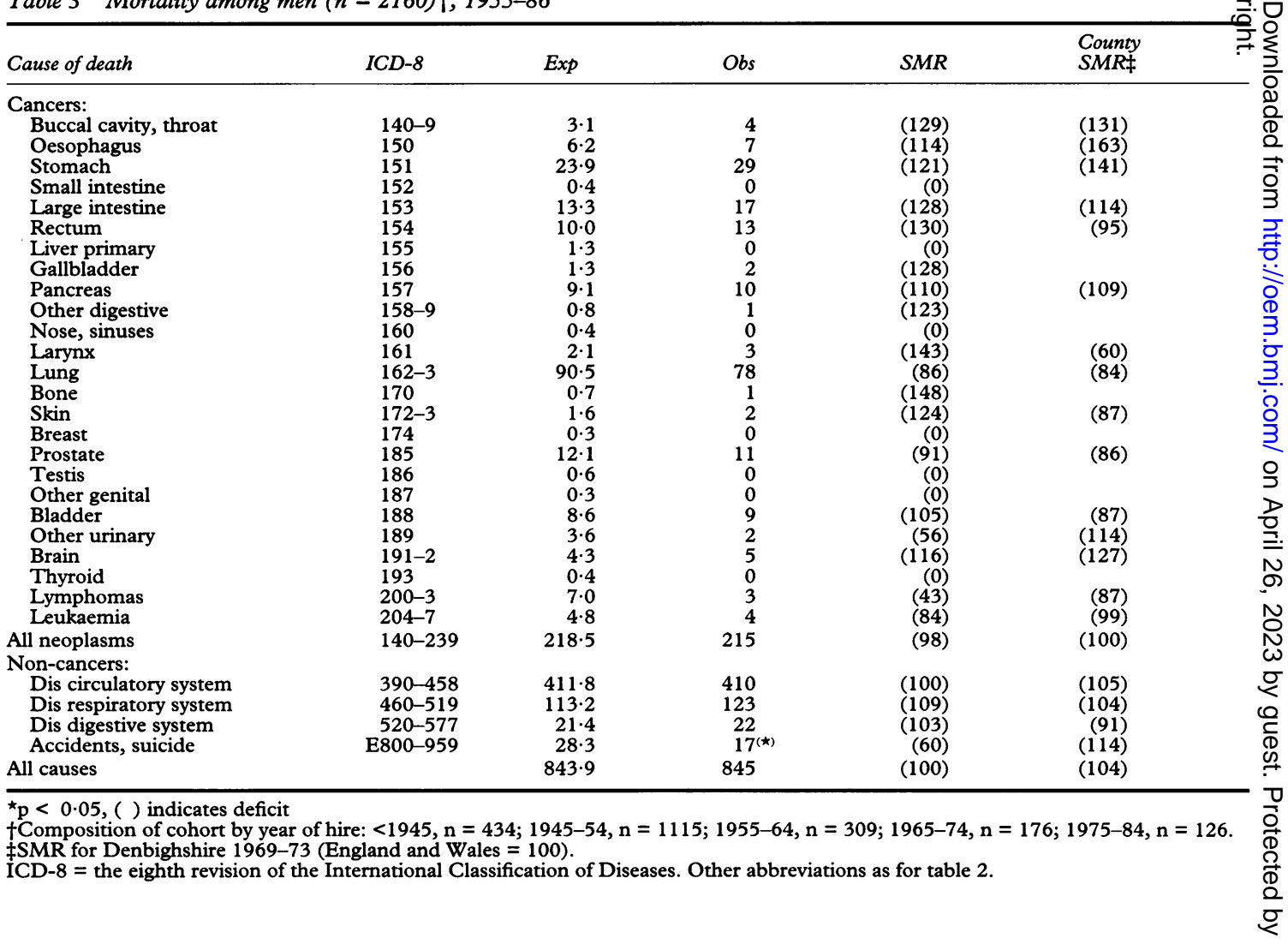


Table 4 Cancer mortality among (1) workers exposed to 2-mercaptolenzothiazole $(M B T)$ and its derivatives ( $n=360$ men), (2) workers exposed to polymerised 2,2,4-trimethyl-1,2-dihydroquinoline (TMQ) ( $n=213$ men), (3) workers employed in the phenyl- $\beta$-napthylamine (PBN) plant $(n=94$ men), and (4) workers exposed to aniline or orthotoluidine $(n=409$ men), $1955-86^{*}$

\begin{tabular}{|c|c|c|c|c|c|c|c|c|c|c|c|c|c|}
\hline \multirow[b]{2}{*}{ Site of cancer } & \multirow[b]{2}{*}{$I C D-8$} & \multicolumn{3}{|c|}{$M B T$} & \multicolumn{3}{|c|}{$T M Q$} & \multicolumn{3}{|c|}{$P B N$} & \multicolumn{3}{|c|}{$\begin{array}{l}\text { Aniline } \\
\text { or orthotoluidine }\end{array}$} \\
\hline & & Obs & $E x p$ & $S M R$ & Obs & $\operatorname{Exp}$ & $S M R$ & $O b s$ & $\operatorname{Exp}$ & $S M R$ & Obs & $\operatorname{Exp}$ & $S M R$ \\
\hline Buccal cavity throat & $140-9$ & 0 & 0.4 & 0 & 0 & 0.3 & 0 & 0 & $0 \cdot 1$ & 0 & 0 & 0.4 & 0 \\
\hline Oesophagus & 150 & 3 & 0.8 & 356 & 0 & 0.5 & 0 & 1 & 0.3 & 311 & 0 & $1 \cdot 0$ & 0 \\
\hline Stomach & 151 & 2 & $3 \cdot 0$ & 66 & 2 & $1 \cdot 8$ & 109 & 3 & $1 \cdot 2$ & 243 & 4 & $3 \cdot 7$ & 108 \\
\hline Small intestine & 152 & 0 & $0 \cdot 1$ & 0 & 0 & 0.0 & 0 & 0 & 0.0 & 0 & 0 & $0 \cdot 1$ & 0 \\
\hline Large intestine & 153 & 5 & $1 \cdot 7$ & 289 & 0 & $1 \cdot 1$ & 0 & 2 & 0.7 & 296 & 3 & $2 \cdot 1$ & 142 \\
\hline Rectum & 154 & 3 & $1 \cdot 3$ & 234 & 1 & 0.8 & 127 & 2 & 0.5 & 394 & 2 & 1.6 & 127 \\
\hline Liver primary & 155 & 0 & 0.2 & 0 & 0 & 0.1 & 0 & 0 & $0 \cdot 1$ & 0 & 0 & $0 \cdot 2$ & 0 \\
\hline Gall bladder & 156 & 0 & $0 . \overline{2}$ & 0 & 0 & $0 \cdot 1$ & 0 & 0 & $0 \cdot 1$ & 0 & 0 & $0 \cdot 2$ & 0 \\
\hline Pancreas & 157 & 0 & $1 \cdot 2$ & 0 & 0 & 0.7 & 0 & 1 & $0 . \overline{5}$ & 209 & 1 & $1 \cdot 5$ & 67 \\
\hline Other digestive & $158-9$ & 0 & 0.1 & 0 & 0 & $0 \cdot 1$ & 0 & 0 & 0.0 & 0 & 0 & 0.1 & 0 \\
\hline Nose, sinuses & 160 & 0 & 0.1 & 0 & 0 & 0.0 & 0 & 0 & 0.0 & 0 & 0 & 0.1 & 0 \\
\hline Larynx & 161 & 0 & 0.3 & 0 & 1 & 0.2 & 609 & 0 & $0 \cdot 1$ & 0 & 1 & 0.3 & 305 \\
\hline Lung & $162-3$ & 12 & $12 \cdot 1$ & 99 & 7 & $7 \cdot \overline{2}$ & 97 & 5 & $4 \cdot 8$ & 103 & 11 & $14 \cdot 7$ & 75 \\
\hline Bone & 170 & 0 & $0 \cdot 1$ & 0 & 0 & $0 \cdot 1$ & 0 & 0 & 0.0 & 0 & 0 & $0 \cdot 1$ & 0 \\
\hline Skin & $172-3$ & 1 & 0.2 & 459 & 0 & $0 \cdot 1$ & 0 & 0 & $0 \cdot 1$ & 0 & 1 & 0.3 & 375 \\
\hline Breast & 174 & 0 & 0.0 & 0 & 0 & 0.0 & 0 & 0 & 0.0 & 0 & 0 & $0 \cdot 0$ & 0 \\
\hline Prostate & 185 & 0 & $1 \cdot 5$ & 0 & 0 & 0.9 & 0 & 0 & 0.6 & 0 & 0 & 1.9 & 0 \\
\hline Testis & 186 & 0 & $0 \cdot 1$ & 0 & 0 & 0.0 & 0 & 0 & 0.0 & 0 & 0 & 0.1 & 0 \\
\hline Other genital & 187 & 0 & $0 \cdot 1$ & 0 & 0 & 0.0 & 0 & 0 & 0.0 & 0 & 0 & 0.1 & 0 \\
\hline Bladder & 188 & 3 & $1 \cdot 1$ & 271 & 0 & 0.7 & 0 & 2 & 0.4 & 451 & 3 & $1 \cdot 4$ & 222 \\
\hline Other urinary & 189 & 1 & 0.5 & 202 & 0 & 0.3 & 0 & 0 & 0.2 & 0 & 2 & 0.6 & 331 \\
\hline Brain & $191-2$ & 2 & 0.6 & 334 & 0 & 0.4 & 0 & 0 & $0 \cdot 2$ & 0 & 0 & $0 \cdot 7$ & 0 \\
\hline Thyroid & 193 & 0 & 0.0 & 0 & 0 & 0.0 & 0 & 0 & 0.0 & 0 & 0 & $0 \cdot 1$ & 0 \\
\hline Lymphomas & $200-3$ & 0 & $1 \cdot 0$ & 0 & 0 & 0.6 & 0 & 0 & 0.4 & 0 & 0 & $1 \cdot 2$ & 0 \\
\hline Leukaemia & $204-7$ & 1 & 0.6 & 160 & 0 & 0.4 & 0 & 0 & $0 \cdot 2$ & 0 & 0 & $0 \cdot 8$ & 0 \\
\hline All neoplasms & $140-239$ & 35 & $28 \cdot 9$ & 121 & 12 & $17 \cdot 4$ & 69 & 16 & $11 \cdot 4$ & 141 & 30 & $35 \cdot 2$ & 85 \\
\hline All causes & & 119 & 106.9 & 111 & 61 & $65 \cdot 3$ & 93 & 54 & $42 \cdot 2$ & 128 & 125 & $130 \cdot 8$ & 96 \\
\hline
\end{tabular}

^Four categories are not mutually exclusive. Abbreviations as for table 2.

Table 5 Mortality by cumulative exposure to 2-mercaptobenzothiazole (MBT), 1955-86

\begin{tabular}{|c|c|c|c|c|c|c|}
\hline Cause of death & $\begin{array}{l}\text { Exposure } \\
\text { level } \\
\left(m g \cdot m^{-3} \cdot y\right)\end{array}$ & Obs & $\operatorname{Exp}$ & $S M R$ & $95 \% C I$ & $\begin{array}{l}p \text { Value } \\
\text { for trend } \dagger \\
\text { (and homogeneity) }\end{array}$ \\
\hline All neoplasms & $\begin{array}{l}\text { None } \\
\quad 0.01-21.24 \\
21 \cdot 25-63.74 \\
\geqslant 63.75\end{array}$ & $\begin{array}{r}180 \\
19 \\
11 \\
5\end{array}$ & $\begin{array}{r}189 \cdot 77 \\
14 \cdot 64 \\
9 \cdot 26 \\
4 \cdot 79\end{array}$ & $\begin{array}{r}95 \\
130 \\
119 \\
104\end{array}$ & $\begin{array}{l}(82-110) \\
(78-205) \\
(59-213) \\
(34-244)\end{array}$ & \multirow{2}{*}{$0.59(0.55)$} \\
\hline Cancer of the bladder & $\begin{array}{l}\text { None } \\
\quad 0 \cdot 01-21 \cdot 24 \\
21 \cdot 25-63.74 \\
\geqslant 63.75\end{array}$ & $\begin{array}{l}6 \\
1 \\
2 \\
0\end{array}$ & $\begin{array}{l}7 \cdot 51 \\
0.54 \\
0 \cdot 36 \\
0 \cdot 20\end{array}$ & $\begin{array}{r}80 \\
184 \\
561 \\
0\end{array}$ & $\begin{array}{c}(29-174) \\
(5-1024) \\
(68-2028) \\
(0-1837)\end{array}$ & \\
\hline
\end{tabular}

${ }^{\star}$ Cut off values of 21.25 and $63.75 \mathrm{mg} \cdot \mathrm{m}^{-3}$.y have been chosen to represent exposures equivalent to five and 15 years in medium exposure jobs.

+ Differences between observed numbers and expectations over the four exposure levels were weighted by the values $0 \cdot 0,10 \cdot 6,42 \cdot 5$, and $134 \cdot 4$.

Abbreviations as for table 2.

both disease groupings, the trend statistic ${ }^{4}$ did not approach statistical significance, and for all neoplasms, the trend across the three exposure levels was downwards.

\section{Discussion}

The overall mortality experience of this cohort, both for all cancers and all non-cancers, was close to (or below) expectation for all periods of follow up (including 30 or more years from first employment). Given the multiple statistical tests carried out in this analysis, a most striking aspect of the results was the lack of statistical significance. None of the site specific SMRs for mortality from cancer was significantly different from 100; this applied to the total study cohort and to the five occupationally exposed sub-cohorts. Numbers of site specific deaths available for analysis among the subcohorts were, however, in general, small, and provide little information for confident interpretation.

More detailed analysis of mortality from bladder cancer was carried out because of clinical concerns at the plant, the striking excess incidence reported 
for a cohort of United States workers exposed to aniline or orthotoluidine, ${ }^{5}$ and the fact that the United States study of MBT workers had focused on this topic (Strauss ME, personal communication). In the study reported here, estimated cumulative exposure to MBT was not found to be a risk factor. The estimates of MBT exposure should, however, be treated with some caution, as hygiene measurements were not available for earlier (and more important) years of the study. Data on smoking histories were, unfortunately, not available, although there is no reason to believe that smoking habits (a risk factor for bladder cancer) would be correlated with estimates of cumulative exposure to MBT.

There was considerable overlap in the membership of the subcohorts, both because some job and department titles involved exposure to more than one chemical and because many workers had more than one job at the plant. Of the 360 men in the MBT subcohort, 45 were members of the PBN subcohort, 191 were members of the aniline or orthotoluidine cohort, and 90 were members of the TMQ cohort (these categories are not mutually exclusive and all members of exposed cohorts would also have experienced other exposures). Two of the three deaths from bladder cancer in the MBT subcohort were among the three deaths from bladder cancer in the aniline or orthotoluidine cohort. If future analyses of these data indicate the $\frac{2}{8}$ existence of occupational hazards, then a quantita- ? tive assessment of exposures both to aniline or $\overrightarrow{\vec{c}}$ orthotoluidine and PBN will assist the correct identification of any hazard.

We thank the Office of Population, Censuses, and Surveys and the Department of Social Security for $\bigcirc$ tracing the study cohort, Mr D J Williams for carry- के ing out the invaluable exposure assessments, Alison $\vec{\circ}$ Taylor and Anne Walker for word processing, and $\overrightarrow{\vec{H}}$ the plant management and workforce for allowing $\vec{\omega}$ the study to be carried out.

1 National Toxicology Program. Toxicology and carcinogenesis studies of 2-mercaptobenzothiazole (CAS No 149-30-4) in $F 344 / N$ rats and $B 6 C 3 F_{1}$ mice. Bethesda: NIH, 1987. (Draft report NTPTR 332. NIH publication No 87-2588).

2 Ogawa Y, Kamato E, Suzuki S, Kobayashi K, Naito K, Kaneko $\mathrm{T}$, et al Toxicity of 2-mercaptobenzothiazole in mice. Eisei Shikenjo Hokoku 1989;107:45-50.

3 Fox AJ, Collier PF. Low mortality rates in industrial cohort studies due to selection for work and survival in the industry. $\mathrm{Br}$ F Ind Med 1976;30:225-30.

4 Breslow NE, Day NE. Statistical methods in cancer research. Vol II-The design and analysis cohort studies. Lyon: International Agency for Research on Cancer, 1987. (Sci publ No 82.)

5 Ward E, Carpenter A, Markowitz S, Roberts D, Halperin W. Excess number of bladder cancers in workers exposed to $\vec{c}$ ortho-toluidine and aniline. I Natl Cancer Inst 1991;88 है 501-6.

Accepted 11 January 1993

\section{Vancouver style}

All manuscripts submitted to the $\mathrm{Br} F$ Ind $\mathrm{Med}$ should conform to the uniform requirements for manuscripts submitted to biomedcical journals (known as the Vancouver style.)

The $B r f$ Ind Med, together with many other international biomedical journals, has agreed to accept articles prepared in accordance with the Vancouver style. The style (described in full in $\mathrm{Br}$ F Ind Med, 24 February 1979, p 532) is intended to standardise requirements for authors.

References should be numbered consecutively in the order in which they are first mentioned in the test by Arabic numerals above the line on each occasion the reference is cited (Manson ${ }^{1}$ confirmed other reports ${ }^{2-5} \ldots$. .). In future references to papers submitted to the $B r \mathcal{F}$ Ind Med should include: the names of all authors if there are six or less or, if there are more, the first three followed by et al; the title of journal articles or book chapters; the titles of journals abbreviated according to the style of Index Medicus; and the first and final page numbers of the article or chapter.

Examples of common forms of references are:

1 International Steering Committee of Medical Editors, Uniform requirements for manuscripts submitted to biomedical journals. Br f Ind Med 1979;1:532-5.

2 Soter NA, Wasserman SI, Austen KF. Cold urticaria: release into the circulation of histamine and eosinophil chemotactic factor of anaphylaxis during cold challenge. $N$ Engl $\mathcal{f}$ Med 1976;294:687-90.

3 Weinstein L, Swartz MN. Pathogenic properties of invading micro-organisms. In: Soderman WA Jr, Soderman WA, eds. Pathologic physiology, mechanisms of disease. Philadelphia: W B Saunders, 1974:457-72.

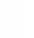

